\title{
The Governance Performance of Selected Barangays in a Highly Urbanized City
}

\author{
Michelle D. Monocay ${ }^{1}$ and Maria Nove A. Mejica ${ }^{2}$ \\ ${ }^{1}$ Farmville Agri Corp., Bacolod City, Philippines \\ 2University of Negros Occidental-Recoletos, Bacolod City, Philippines
}

\begin{tabular}{l} 
Article history \\
Submitted: 13 July 2020 \\
Revised: 5 November 2020 \\
Accepted: 16 November 2020 \\
\hline Keywords \\
Public Administration \\
Barangay Governance \\
Performance \\
Service Delivery \\
Descriptive-Comparative \\
Highly Urbanized City \\
Philippines
\end{tabular}

Introduction. The Philippines has enacted several policies to continually elevate the performance of its governance. As such, the Department of Interior and Local Government (DILG) implemented the Seal of Good Local Government (SGLG) Award to improve the governance performance of the local government units (LGUs). A highly urbanized city in the Province of Negros Occidental is a recipient of this award and other several recognitions. However, lingering issues such as high incidence of malnutrition, lack of access to potable water, excessive flooding due to drainage and sewerage problems, and several concerns in solid waste management implementation triggered questions on the eligibility of these awards. Thus, this study investigated the level of governance performance of selected barangays in the areas of social services, peace and order, disaster management, andenvironment management when taken as a whole and grouped according to income and population. Also, it sought to find out if a significant difference exists in the level of governance performance of the barangay councils when they are grouped according to mentioned demographics.

Methods. This study used a descriptive-comparative research design to describe and compare the level of governance performance of the top five most and least populated barangays. The respondents were the 114 community leaders selected through stratified random sampling. A properly validated and reliable researcher-made questionnaire based on the assessment criteria of DILG Memorandum Circular No. 2018-194 or the Seal of Good Local Governance for Barangay (SGLGB) was used to gather the evaluation of the respondents. The data gathered were analyzed using Mean, Standard Deviation, and Mann Whitney U test.

Results. Findings showed that the selected barangays have a high level of governance performance in the areas of social service, peace and order, disaster management, and environment management. When grouped according to income and population, the participating barangays have a high level of governance performance except in areas of environment management, which presented that the low income and least populated barangays have an average level of governance performance. Results also showed a significant difference in the level of governance performance in the areas of social service, disaster management, and environment management when grouped according to income and population. In the area of peace and order, the barangays exhibited no significant difference in their level of governance performance when grouped according to income and population.

Conclusion. The selected barangays perform well in the various areas of governance except in the area of environmental management where low-income and least populated barangays still need to improve their services especially on the greening and conservation programs. The results also imply that the HUC has cascaded its support and services to its component barangays, thus, it deserves of all its awards and recognitions. On the other hand, the absence of significant difference in the area of peace and order only shows the consistency of all barangays when it comes to the implementation of the peace and order program. The coordination of the LGU with the Philippine National Police (PNP) is strong and the presence of Bac-Up stations which closely supervise barangays under their jurisdiction proves to be effective. Finally, the results shows adherence to President Duterte's fight against criminality and illegal drugs and DILG's advocacy for the Matino, Mahusay at Maasahang barangay. 
Practical Value of the Paper. The study significantly contributes to the few existing literature on governance performance at the barangay level. The results of the study provided baseline information for policy recommendations to improve the delivery of services of barangays.

\section{References}

Agustin, C. P., Rovero, J., Paraon, C. L., Taguinod, R., \& Turingan, I. (2018). Functionality of barangay anti-drug abuse Council: its roles and responsibilities under DILG memorandum circular no. 2015-66. International Journal of Advanced Research in Management and Social Sciences, 7(2), 29-49.

Boris, O. H. (2015). Challenges confronting local government administration in efficient and effective social service delivery: The Nigerian Experience. International Journal of Public Administration and Management Research, $2(5), 12-22$

Boysillo, S. L. (2017). Governance of the Barangay Chairpersons in the Municipality of Ubay Bohol. International Journal of Business and Management Studies, 9(1), 50-63.

Cabangan, S. D. (2019). The Operation of Barangay Anti-Drug Abuse Council (BADAC) in Cabagan, Isabela. International Journal of Advanced Research in Management and Social Sciences, 8(10), 206-233.

Caldo, R. B. (2015). Assessment of Competency Measures of Barangay Council in San Jose, Sto. Tomas, Batangas. DLSU Research Congress 2015. De La Salle University, Manila, Philippines, March 2-4, 2015.

Canare, T. (2016). The Relationship between IRA and Local Government Expenditures: Evidence from a Cross-Section of Philippine Cities. Philippine Political Science Journal, 37(3), 167-189.

De los Santos, M. C. M. (2016, April). Local Government Units' Environmental Governance for Economic Sustainability. In International Conference on Management, Leadership \& Governance (p. 68). Academic Conferences International Limited.

Frivaldo, F. S., Sadera, J. M., \& Bueno, D. C. (2019). Harmonizing Good Governance across Barangays in a Metropolitan Setting. Institutional Multidisciplinary Research and Development Journal, 2, 184-191.

Habiatan, E. N. (2019). The Barangay Peace and Order Council of Cabagan, Isabela. International Journal of Advanced Research in Management and Social Sciences, 8(10), 415-441.

Ibok, E. E. (2014). Local Governance and Service Delivery in Nigeria. Caribbean Journal of Science and Technology, $2,536-541$.

\section{Correspondence:}

Michelle D. Monocay [mdulaca18@gmail.com]

http://orcid.org/0000-0002-6796-0159 